\title{
Yurt Dışı Eğitim ve İkinci Dil Öz-Yeterlik İnançları Öıçeği
}

\author{
Emre Güvendir ${ }^{1}$, Meltem Acar-Güvendir ${ }^{2}$, Sinem Dündar ${ }^{1}$

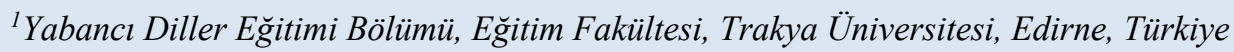 \\ ${ }^{2}$ Eğitim Bilimleri Bölümü, Eğitim Fakültesi, Trakya Üniversitesi, Edirne, Türkiye
}

Sorumlu Yazar: Emre Güvendir, emreguvendir@trakya.edu.tr

Makale Türü: Araştırma Makalesi

Kaynak Gösterimi: Güvendir, E., Acar-Güvendir, M., \& Dündar, S. (2020). Yurt Dışı Eğitim ve İkinci Dil Öz-Yeterlik İnançları Ölçeği. Eğitimde Kuram ve Uygulama, 16(2), 215-230. Doi: 10.17244/eku.756445

\section{Study Abroad and L2 Self-Efficacy Beliefs Scale}

Emre Güvendir ${ }^{1}$, Meltem Acar-Güvendir² ${ }^{2}$ Sinem Dündar ${ }^{1}$

${ }^{1}$ Department of Foreign Language Education, Faculty of Education, Trakya University, Edirne, Turkey

${ }^{2}$ Department of Educational Sciences, Faculty of Education, Trakya University, Edirne, Turkey

Corresponding Author: Emre Güvendir, emreguvendir@trakya.edu.tr

Article Type: Research Article

To Cite This Article: Güvendir, E., Acar-Güvendir, M., \& Dündar, S. (2020). Yurt Diş1 Eğitim ve İkinci Dil Öz-Yeterlik İnançları Ölçeği. Eğitimde Kuram ve Uygulama, 16(2), 215-230. doi: 10.17244/eku.756445 


\title{
Yurt Dışı Eğitim ve İkinci Dil Öz-Yeterlik İnançları Ölçeği
}

\author{
Emre Güvendir ${ }^{1}$, Meltem Acar-Güvendir ${ }^{2}$, Sinem Dündar ${ }^{1,3}$ \\ ${ }^{\text {I} Y a b a n c ı ~ D i l l e r ~ E g ̆ i t i m i ~ B o ̈ l u ̈ m u ̈, ~ E g ̆ i t i m ~ F a k u ̈ l t e s i, ~ T r a k y a ~ U ̈ n i v e r s i t e s i, ~ E d i r n e, ~ T u ̈ r k i y e ~}$ \\ ${ }^{2}$ Eğitim Bilimleri Bölümü, Eğitim Fakültesi, Trakya Üniversitesi, Edirne, Türkiye \\ ${ }^{1}$ ORCID: http://orcid.org/0000-0003-3088-0136 \\ ${ }^{2}$ ORCID: http://orcid.org/0000-0002-3847-0724 \\ ${ }^{3}$ ORCID: http://orcid.org/0000-0001-5076-2087
}

\section{$\ddot{\mathbf{O Z z}}$}

$\mathrm{Bu}$ çalışmanın amacı öğrencilerin yurt dışında dil eğitiminin sonunda ulaşabilecekleri yetkinliklere ilişkin öngördükleri öz-yeterlik inançlarını ve beklentilerini önceden tespit edecek bir veri toplama aracı geliştirmektir. Çalışma 607 üniversite öğrencisi üzerinde, 2018-2019 akademik yılında gerçekleştirilmiştir. Ölçeğin faktör yapısını ortaya koymak için açımlayıcı (AFA) ve doğrulayıcı (DFA) faktör analizleri uygulanmıştır. AFA sonucunda öz değerleri 1'den büyük 24 maddeden oluşan dört faktörlü bir yap1 ortaya çıkmıştır. Bu dört faktörün toplam varyansın \%61.48'ini açıkladığ 1 görülmüştür. Maddelerin faktör yük değerleri .50 ile .79 arasında değişmektedir. Elde edilen dört faktörlü yapının doğrulanıp doğrulanmadığını test etmek için ikinci bir çalışma grubu üzerinde DFA uygulanmıştır. Modelin yeterliğini ortaya koymak amacıyla incelenen uyum indekslerinin iyi uyuma işaret ettiği görülmektedir. Bu çalışmadan elde edilen bulgular, Yurt Dışı Eğitim ve İkinci Dil Öz-Yeterlik İnançları Ölçeğinin, yurt dışında dil kursuna gitmeyi amaçlayan öğrencilerin dil eğitiminin sonunda ulaşabilecekleri yetkinliklere ilişkin öngördükleri özyeterlik inançlarının ve beklentilerinin önceden belirlenmesinde kullanılabilecek geçerli ve güvenilir bir ölçme aracı olduğunu ortaya koymaktadır.
\end{abstract}

\section{Makale Bilgisi}

Anahtar kelimeler: Öğrenci

beklentileri, Öğrenci inançları, Ölçek geliştirme, Öz-yeterlik, Yurt dışı eğitim

Makale Geçmişi:

Geliş: 22 Haziran 2020

Düzeltme: 15 Aralık 2020

Kabul: 22 Aralık 2020

Makale Türü: Araştırma Makalesi

\section{Study Abroad and L2 Self-Efficacy Beliefs Scale}

\begin{abstract}
The aim of this study is to develop a data collection tool that will measure students' selfefficacy beliefs and expectations regarding the competencies they can achieve at the end of their language education abroad. The participants of the study include 607 university students. Data were collected during the 2018-2019 academic year. Exploratory and confirmatory factor analyses were applied to reveal the factor structure of the scale. As a result of the exploratory factor analysis, a four-factor structure consisting of 24 items with eigenvalues greater than 1 emerged. These four factors explained $61.48 \%$ of the total variance. Factor load values of items varied between .50 and .79. Confirmatory factor analysis was performed on a second study group to confirm the four-factor structure obtained from the exploratory factor analysis. The fit indices that were examined in order to display the adequacy of the model indicated a good fit. The findings obtained from this study reveal that the Study Abroad and L2 Self-Efficacy Beliefs Scale is a valid and reliable measurement tool that can be used to measure the projected self-efficacy beliefs and expectations of students who intend to attend a language course abroad.
\end{abstract}

\section{Article Info}

Keywords: Scale development, Self-efficacy, Student beliefs, Student expectations, Study abroad

\section{Article History:}

Received: 22 June 2020

Revised: 15 December 2020

Accepted: 22 December 2020

Article Type: Research Article 


\section{Extended Summary}

\section{Introduction}

One of the most important reasons for learners to attend a language course abroad is to improve foreign language proficiency. Accordingly, students have some predictions and expectations regarding the competencies and skills they will have at the end of studying abroad (Güvendir, 2017; Surtees, 2016). Therefore, more research is needed on the impact of pre-existing beliefs and expectations of students on their study abroad experiences (Zaykovskaya, Rawal, \& De Costa, 2017). This study aimed to develop a valid and reliable measurement tool that can be used to measure the projected self-efficacy beliefs and expectations of the students who intend to attend a language course abroad. This study aims to support future research that will focus on foreign language education and self-efficacy.

\section{Participants}

\section{Method}

The participants of study included 607 students studying at the Trakya University Faculty of Education during the 20182019 academic year. The research was carried out on two groups. Exploratory factor analysis was performed to reveal the factor structure of the scale over 453 people, and confirmatory factor analysis was performed over 154 people to confirm the obtained factor structure on another study group.

\section{Data Collection Tools}

The data collection tool developed by the researchers consisted of two parts. The first part of the tool involved demographic questions regarding students' gender, age, department, and English levels. The second part of the tool included the scale items.

In the item writing phase of the scale, expressions regarding the skill-based competencies of the learners, which are included in the Common European Framework of Reference for Languages (2013) were taken as a reference.

\section{Data Analysis}

Experts' opinions were consulted for the content validity of the scale. Exploratory and confirmatory factor analyzes were applied to reveal the factor structure of the scale. Cronbach $\alpha$ internal consistency coefficient was calculated to specify the reliability of the scale.

\section{Findings}

As a result of the exploratory factor analysis, a four-factor structure consisting of 24 items with eigenvalues greater than 1 emerged. These four factors explained $61.48 \%$ of the total variance. Factor load values of items varied between .50 and .79. Confirmatory factor analysis was performed on a second study group to confirm the four-factor structure obtained from the exploratory factor analysis. The fit indices that were examined in order to display the adequacy of the model indicated a good fit.

\section{Discussion and Suggestions}

Considering the popularity of language education abroad, it is necessary to examine what beliefs and expectations students have before stepping into this process (Surtees, 2016). Although there are studies on the foreign language learning beliefs of students, one of the issues ignored in the literature is the effect of students' projected beliefs and expectations on their experience abroad. The findings obtained from this study reveal that the Study Abroad and L2 Self-Efficacy Beliefs Scale is a valid and reliable measurement tool that can be used to measure the projected selfefficacy beliefs and expectations of the students who intend to attend a language course abroad. 


\section{Giriş}

Uluslararası düzeyde bilgiye ulaşabilmek, değişen dünyanın dinamiklerini takip edebilmek ve mesleki olarak uluslararası rekabet ortamında yer bulabilmek için yabancı dil öğrenmek bireyler adına önemli bir zorunluluk haline gelmiştir. Bunun yanı sıra, yabancı dil öğrenmek insanların küreselleşen dünyanın sunduğu olanaklarla farklı kültürleri tanıyarak kendilerini hem mesleki hem de kişisel anlamda geliştirmesine firsat sunması bakımından gitgide önem kazanmaktadır. Son yıllarda yabancı dili, yurt dışında öğrenmeyi tercih edenlerin sayısında da artı̧̧ olduğu gözlemlenmektedir. Uluslararas1 Dil Merkezleri Birliği'nin (IALC) (2016) araştırma raporuna göre, dünyada her yıl toplam 2.28 milyon öğrenci yabancı dil öğrenmek için yurt dışına gitmektedir. Bu sayı tüm dünyada yabancı dil öğrenenlerin \% 0.25'ini yansıtırken, bunların ortalama \% 61'ini İngilizce öğrenmek için yurt dışını tercih edenler oluşturmaktadır.

Yapılan araştırmalar bireylerin yurt dışında dil eğitimi alma tercihlerinin temelinde yurt dişında dil eğitiminin onlara dili aktif olarak kullanma olanakları sunacağ 1 ve bu sürecin dil öğrenimini hızlandıracağı inancının bulunduğunu göstermektedir (Allen \& Dupuy, 2012; Güvendir, 2017; Tanaka \& Ellis, 2003; Zemach-Bersin, 2009). Öğrenciler, yurt dışı eğitiminin kendilerine sınıf içi eğitime ek olarak sınıf dışında da dile doğal yollarla maruz kalma olanaklarını sunacağını düşünmektedir (Tanaka \& Ellis, 2003). Güvendir (2017), ABD’de kısa süreli İngilizce programında yer alan Türk öğrencilerle yaptığ 1 görüşmelerde, öğrencilerin kursa başlamadan önce yurt dışı dil eğitimiyle ilgili beklentilerinin yüksek olduğunu ve katılımcıların büyük çoğunluğunun doğal yollarla dile maruz kalarak İngilizce seviyelerini kısa sürede önemli miktarda arttıracaklarına inandıklarını tespit etmiştir.

Türkiye'de gerek devlet okullarında gerekse özel okullar ve dil kurslarında yabancı dil eğitimi verilmesine rağmen, yabancı dili yurt dışında öğrenmek isteyen öğrenci sayısında son zamanlarda artış olduğu görülmektedir. Dünya genelinde yurt dışına en çok öğrenci gönderen ülkelerinden biri olan Türkiye, Avrupa ülkeleri arasında Amerika Birleşik Devletleri'ne (ABD) en fazla öğrenci gönderen ülke konumundadır (ICEF Monitor, 2017). Bu öğrencilerin bir bölümü lisansüstü eğitim, lisans eğitimi ve öğrenci değişim programları çerçevesinde yurt dışında bulunurken, giden öğrencilerin önemli bir kesimi yabancı dil öğrenmek için yurt dışını tercih etmektedir. Bu sayının yüksek olmasının en büyük nedenlerinden biri, Türkiye'de yabancı dil eğitiminin hedeflenen kazanımlara ulaşmak konusunda yetersiz olmasıdır. 2019 İngilizce Yeterlilik Endeksi verilerine göre, Türkiye dünyada 100 ülke arasından 79. sırada yer alarak İngilizce yeterlilik açısından çok düşük bir düzeye sahiptir (EF EPI, 2019). Aynı endekste Türkiye, 33 Avrupa ülkesi arasından 32. sırada yer almaktadır. Ayrıca 2011 yılından bu yana Türkiye açısından İngilizce Yeterlilik Endeksi verileri incelendiğinde ortaya çıkan görüntünün düşük ve çok düşük seviyesinde yer aldığı görülmektedir. Yurt içinde verilen yabancı dil eğitiminin öğrencileri istenilen seviyelere taşıyamaması, birçok bireyin yabancı dil eğitimi konusunda yeni arayışlara girmesine neden olmaktadır (Güvendir, 2017).

Öğrencilerin tercih ettikleri seçeneklerden birisi de yurt dışında dil eğitimi almaktır. British Council (2012) tarafindan hazırlanan Student Insight-Turkey raporuna göre, 2007 ve 2012 yılları arasında Türkiye'den 15.000 öğrenci İngiltere'de dil eğitimi almak için bulunmuştur. Bu öğrencilerin İngiliz ekonomisine katkıları 86 milyon Pound olarak açıklanmıştır. 2013 yılında British Council'ın 4816 Türk öğrencinin katılımıyla yaptığı bir çalışmada, katılımcıların yurt dışında eğitim görmekle ilgili istekleri ve düşünceleri araştırılmıştır. Katılımcıların \% 95'inin yurt dışında eğitim görmek istediği, \% 96'sının yurt dışında eğitim görmenin ileride daha iyi iş imkanı sağlayacağına inandığı ve \% 32'sinin yurt dışında eğitim görmenin gelecekte daha iyi eğitim firsatlarına ulaşımı kolaylaştırcağı fikrine sahip oldukları tespit edilmiştir. Yine aynı çalışma, Türk öğrencilerin yurt dışında eğitim görmek için sırasıyla en çok İngiltere, Amerika, Almanya ve Kanada ülkelerini tercih ettiklerini ortaya koymuştur.

Yurt dışında yabancı dil eğitimine olan talebe rağmen, bu eğitimi tamamlamış öğrenciler üzerinde gerçekleştirilen araştırmalar öğrenci başarısını etkileyen birçok faktör bulunduğunu ve yurt dışı dil eğitiminden herkesin aynı oranda faydalanamadığını ortaya koymuştur (Kinginger, 2008). Örneğin bazı çalışmalar yurt dışında yabancı dil eğitimi almanın dinleme becerileri (Cubillos, Chieffo, \& Fan, 2008), okuma becerileri (Dewey, 2004), yazma becerileri (PérezVidal \& Juan-Garau, 2009) akıcı konuşma (Segalowitz \& Freed, 2004), sesletim (Díaz-Campos, 2004), sözcük bilgisi (Foster, 2009) ve dilin yapısı (JuanGarau, 2014) üzerinde olumlu etkileri olduğunu tespit ederken, yapılan diğer araştırmalar yurt dışında bulunmanın ve alınan eğitimin etkisiz olduğu ya da çok az etkisinin olduğu sonucuna ulaşmıştır (Badstübner \& Ecke, 2009; DeKeyser, 1990; 1991; Mendelson, 2004; Milton \& Meara, 1995; Pellegrino-Aveni, 1998; Segalowitz et al., 2004; Tanaka, 2007). Güvendir (2017), yurt dışında bulunan Türk öğrencilerle gerçekleştirdiği görüşmelerde öğrencilerin beklemedikleri birçok sorunla karşılaştıklarını ve yurt dışında yaşadıkları tecrübelerin beklentilerinden çok farklı olabildiğini tespit etmiştir.

Yurt dışında yabancı dil eğitimi ve öğrenci başarısı üzerine yapılan araştırmalar, yurt dışında bulunmanın her birey için dilsel gelişim anlamında faydalı olmadığını göstermelerine rağmen, birçok öğrencinin yabancı dili öğrenmenin en iyi yollardan birinin yurt dışında eğitim görmek olduğuna inandığı yaygın olarak bilinen bir gerçektir. Öğrencilerin yabancı dil öğrenimine ilişkin geliştirdiği inançlar ve beklentiler, yabancı dil öğrenme sürecinde önemli bir rol oynamaktadır (Zaykovskaya, Rawal, \& De Costa, 2017). Surtees (2016), bu inançları dil ideolojileri çerçevesinde ele alarak, bireyin ötesinde tarihsel ve sosyal açıdan bu inançların ortaya çıkmasındaki bazı rollerin incelenmesi gerektiğine dikkat çekmektedir. Dil ideolojileri, "bireylerin sosyal hayatlarında kullandıkları dil(ler)le ilgili geliştirdikleri inançlar 
veya duygular" (Kroskrity, 2004, p. 498) olarak tanımlanabilir. Yurt dışı eğitimi alanında yapılan çalışmalar yabancı dille ilgili inançlara ve beklentilere ait birçok konuyu ele almıştır. Bu konular, yabancı dile yönelik tutum, aile yanında konaklama hakkındaki inançlar, yurt dişı eğitim almak için gerekli motivasyon ve dil öğreneni olarak bireyin benlik algısı hakkındaki değişiklikler gibi birçok değişkeni içermiştir. Bu doğrultuda, yabancı dil eğitiminde bilişsel özelliklerin yanı sıra güdülenme, tutum ve öz-yeterlik gibi duyuşsal özellikler de öğrencilerin inançlarını ve beklentilerini etkileyen unsurlar olarak önemli bir yere sahiptir (Yanar \& Bümen, 2012).

Bu unsurlardan öz-yeterlik kavramı, Bandura'nın Sosyal Bilişsel Kuramıyla ortaya çıkmış ve "verilen kazanımların sağlanması için bireylerin gerekli davranış biçimlerini düzenleme ve yürütme yetkinliklerine ilişkin inançları" (Bandura, 1997, p. 3) olarak tanımlanmıştır. Öz-yeterlik kavramı bireyin öğrenme sürecinde neyi, ne kadar yapabileceğine yönelik kendine olan güvenini ifade etmektedir. Sosyal Bilişsel Kuramı çevre, davranış ve fiziksel, bilişsel ve duyuşsal özellikleri içeren kişisel unsurlar arasındaki karşılıklı etkileşimin önemini savunmaktadır (Bandura, 1986). Bu kurama göre, bu unsurlar arasındaki etkileşimden dolayı bireylerin başarabileceklerine ilişkin inançları yaptıkları iş için gösterdikleri çabayı belirlemektedir (Bandura, 1999; Schnunk, 2003). Bireyin kendi performansı öz-yeterliği ölçmek için en güvenilir rehber olmaktadır. Bu anlamda, başarı öz-yeterliği artırırken, başarısızlık öz-yeterliği düşürmektedir (Bandura, 1986). Görüldüğü üzere, öz-yeterlik inançları, bireylerin düşünceleri ve kendilerini nasıl motive ettikleri başarmak için yaptıkları çalı̧̧malar açısından büyük önem taşımaktadır (Tilfarlıŏlu \& Çiftçi, 2011).

Bandura'ya (1994) göre, bireylerin öz-yeterlikleri hakkındaki inançları üzerinde dört temel etki kaynağı bulunmaktadır. Bunlar sırasıyla, başarıya ilişkin doğrudan yaşantılar, gözleme dayalı dolaylı yaşantılar, sözel ikna ve psikolojik ve fizyolojik durumlardır. Güçlü öz-yeterlik geliştirmenin birinci ve en etkili yolu başarıya ilişkin doğrudan yaşantılar sayesinde olur (Bandura, 1994). Başarı bireyde sağlam bir öz-yeterlik inancı oluşturur. Öz-yeterlik inancını oluşturmada ve güçlendirmedeki ikinci yol gözleme dayalı dolaylı yaşantılardır. Bireylerin kendileri gibi uzun süreli çabayla başarılı olan kişileri gözlemlemesi, kendilerinin de benzer faaliyetleri yapabilecekleri inancını arttırmaktadır (Bandura, 1994). Sözel ikna ise, bireylerin inançlarını güçlendiren diğer bir unsurdur. Diğer kişilerden gelen bireylerin başarabilecek kapasiteye sahip oldukları hakkındaki ikna edici sözler, bireylerde olumlu etki bırakmaktadır. Öz-yeterlik inancını geliştirmenin son aşaması ise bireylerin stres içeren tepkilerini azaltmak ve olumsuz duygusal eğilimlerini değiştirmektir (Bandura, 1994).

Bandura (1977) aynı zamanda, bireylerin başarıya ulaşmak için istediği sonuca varmalarını sağlayan iki temel beklentiden söz etmektedir. Bunlar, öz-yeterlik inancı beklentisi ve sonuç beklentileridir. Öz-yeterlik inancı beklentisi, bir davranışın başarısına yönelik olan inançtır. Diğer bir deyişle, bireyin istediği sonuca ulaşabilmek için yapması gereken işleri başarıp başaramayacağına yönelik geliştirdiği inançlardır. Sonuç beklentileri ise öz-yeterlik inancından farklı olup, bireyin bir davranışın sonuçlarıyla ilgili olan beklentileridir (Hackett \& Betz, 1981). Bu doğrultuda, olumlu sonuç beklentisi geliştiren bireyler, yüksek öz-yeterlik inancına sahip olurlar. (Landry, 2003). İyi yapıldığı takdirde başarılı sonuçlar veren birçok davranış bulunurken, başarı konusunda yeteneklerinden şüphe eden bireyler bu anlamda olumlu inanç geliştirememektedir (Betz \& Hackett, 1986). Diğer bir deyişle, öz-yeterliği yüksek olan bireyin başarı beklentisi yüksek olmaktadır (Bandura, 1997).

Son yıllarda, yabancı dil eğitiminde öz-yeterlik kavramına yönelik birçok çalışmanın yer aldığı görülmektedir. Alanyazın incelendiğinde, yabancı dil eğitiminde öz-yeterlik daha çok başarı (Chen, 2007; Yılmaz, 2011), dil öğrenme stratejileri (Balaman-Uçar, 2016; Bonyadi, Nikou, \& Shahbaz, 2012; Magogwe \& Oliver, 2007; Yang, 1999; Wong, 2005), kaygı (Çubukçu, 2008; Mills, Pajares, \& Herron, 2006; Torres \& Turner, 2016) ve motivasyon (Busse, 2013; Wolters \& Rosenthal, 2000) gibi faktörlerle ilişkisi açısından ele alınmıştır. Yapılan çalışmalar öz-yeterlik inancının bu faktörler ile olumlu ilişkiye sahip olduğunu ortaya koymaktadır. Öz-yeterlik inancı gelişmiş bireylerin yabancı dil başarılarının daha yüksek olduğu, dil öğrenme stratejilerini daha fazla kullandıkları, daha az yabancı dil kaygısı yaşadıkları ve yabancı dil öğrenmeye yönelik motivasyonlarının daha yüksek olduğu gözlemlenmiştir.

Yurt dışında yabancı dil eğitimi ve bireylerin öz-yeterlik inancı arasındaki ilişki bazı araştırmacılar tarafından ele alınmıştır. Bu çalışmalar, genel olarak yurt dışında yabancı dil programlarına katılmanın öz-yeterlik üzerindeki etkisine yoğunlaşmıştır. Yapılan çalışmaların bir bölümü yabancı dili yurt dışında öğrenmenin öğrencilerin öz-yeterlik inançları üzerinde önemli değişiklikler meydana getirdiği sonucuna ulaşmıştır. Örneğin, Tanaka ve Ellis'in (2003), 166 Japon üniversite öğrencisinin katılımıyla gerçekleştirdiği çalışmada, katılımcılar ABD'de özel bir üniversitede 15 haftalık yurt dışı eğitim programına katılmışlardır. Çalışmanın sonucunda, İngilizce konuşulan bir ülkede yaşamak ve yoğun bir şekilde anadili İngilizce olan öğretim elemanları tarafından eğitim almak, katılımcıların öz-yeterlik inançlarına olumlu yönde etki etmiştir. Yine, Cubillos ve Ilvento'nun (2013), Fransa ve İspanya'da kısa süreli ve yarıyıl zamanlı olarak akademik programlara katılan 39 ABD'li öğrenciyle yaptığı çalışma, eğitim süresine ve gidilen yere bakılmaksızın yurt dışı eğitim programına katılmanın öz-yeterlik inancı açısından tüm yabancı dil becerilerinin (okuma, yazma, dinleme, konuşma) üzerinde anlamlı bir etki yarattığını ortaya koymuştur. Petersdotter, Niehoff ve Freund (2017) tarafindan yapılan diğer bir çalışmada ise, yurt dışında eğitim görmenin öğrencilerin öz-yeterlik inanç algılarını etkilediği görülmüştür. Bu çalışmaların sonuçlarından farklı olarak Kaypak ve Ortaçtepe'nin (2014), 5 ay boyunca yurt dış1 değişim programına katılan Türk öğrenciler ile yaptığı çalışma, öğrencilerin dil öğrenimiyle ilgili inançlarında bir değişiklik görülmediği sonucuna varmıştır. Amuzie ve Winke (2009), yurt dışında eğitim için daha uzun süre kalan 
öğrencilerin, kısa süreli kalanlara oranla öz-yeterlik inançlarının daha fazla gelişmiş olduğunu tespit etmiştir. Görüldüğü üzere, yapılan çalışmalar, öncelikle yurt dış1 eğitimi deneyiminin öz-yeterlik inancında yarattığı etkileri araştırmıştır. $\mathrm{Bu}$ anlamda, öz-yeterlik inancının yurt dışında eğitim alma düşüncesini nasıl etkilediği konusunda alanyazında yeterli sayıda çalışma bulunmamaktadır. Ayrıca öğrencilerin yurt dışında almayı hedefledikleri yabancı dil eğitiminin sonunda ulaşabilecekleri yetkinliklere ilişkin öngördükleri öz-yeterlik inançlarını ve beklentilerini konu alan çalışmalar bulunmamaktadır.

Öğrenenlerin yurt dışında dil kursuna katılmalarının en önemli nedenlerinden birisi yabancı dillerinde gelişim kaydetmektir. Bu doğrultuda öğrenciler yurt dışında bulunmanın sonunda sahip olacakları yetkinliklerle ve becerilerle ilgili bazı tahminlere ve beklentilere sahiptirler (Güvendir, 2017; Surtees, 2016). Dolayısıyla, yabancı dil öğrencilerinin yurt dışı eğitimi konusunda başarılı olmalarını sağlayan faktörlerin araştııılması ve yurt dışında dil eğitimi üzerine yapılacak araştırmaları geliştirmek adına öğrencilerde önceden var olan inançların ve beklentilerin etkisi üzerine daha fazla araştırma yapılması gerekmektedir (Zaykovskaya et al., 2017). Özellikle Türkiye'de yurt dışı dil eğitimi bağlamında öğrencilerin öz-yeterlik beklentileriyle ilgili çok az çalışma olduğu ve araştırmalarda kullanılacak geçerli ve güvenilir bir ölçme aracının olmadığı görülmektedir. Bu çalışmanın amacı öğrencilerin yurt dışında dil eğitiminin sonunda ulaşabilecekleri yetkinliklere ilişkin öngördükleri öz-yeterlik inançlarını ve beklentilerini, öğrenciler yurt dışına gitmeden önce tespit edecek bir veri toplama aracı geliştirmektir. İleride yurt dışı dil eğitimi ve öz-yeterlik konusunda yapılacak olan araştırmaların desteklenmesi ve alanyazında bulunan eksikliğin giderilmesine yardımcı olması açısından çalışmanın alana katkıda sunması hedeflenmektedir.

\section{Çalıșma Grubu}

\section{Yöntem}

Araştırmanın çalışma grubunu, 2018-2019 akademik yılında, Trakya Üniversitesi Eğitim Fakültesinde öğrenim görmekte olan toplam 607 öğrenci oluşturmaktadır. Araştırma iki çalışma grubu üzerinde yürütülmüştür. 453 kişi üzerinden ölçeğin faktör yapısını ortaya koyabilmek için açımlayıcı faktör analizi (AFA), elde edilen faktör yapısını başka bir çalışma grubu üzerinde doğrulamak için 154 kişi üzerinden doğrulayıcı faktör analizi (DFA) yapılmıştır. Tablo 1’de AFA ve DFA kanıtlarının elde edildiği 607 öğrencinin demografik bilgileri sunulmuştur.

Tablo 1. AFA ve DFA kanıtlarının elde edildiği çalışma grubuna ilişkin demografik bilgiler

\begin{tabular}{|c|c|c|}
\hline Cinsiyet & f & $\%$ \\
\hline Erkek & 427 & 70.3 \\
\hline Kadın & 180 & 28.7 \\
\hline Bölüm & $\mathbf{f}$ & $\%$ \\
\hline Bilgisayar ve Öğretim Teknolojileri & 28 & 4.6 \\
\hline Resim Eğitimi & 28 & 4.6 \\
\hline Müzik Eğitimi & 28 & 4.6 \\
\hline İlköğretim Matematik Eğitimi & 32 & 5.3 \\
\hline Türkçe Eğitimi & 32 & 5.3 \\
\hline Sosyal Bilgiler Eğitimi & 85 & 14.0 \\
\hline Fen Eğitimi & 88 & 14.5 \\
\hline Özel Eğitim & 87 & 14.3 \\
\hline Rehberlik ve Psikolojik Danışmanlık & 39 & 6.4 \\
\hline Sınıf Eğitimi & 160 & 26.4 \\
\hline Yaş & f & $\%$ \\
\hline $17-19$ & 67 & 11.0 \\
\hline $20-23$ & 495 & 81.5 \\
\hline $24-27$ & 35 & 5.8 \\
\hline 27 ve üzeri & 10 & 1.6 \\
\hline Toplam & 607 & 100 \\
\hline Seviye & $\mathbf{f}$ & $\%$ \\
\hline A1 & 246 & 40.5 \\
\hline $\mathrm{A} 2$ & 303 & 49.9 \\
\hline $\mathrm{B} 1$ & 58 & 9.5 \\
\hline
\end{tabular}

Tablo 1'e göre, öğrencilerin \%70.3'ü kadınken, \%29.7'si ise erkektir. Öğrencilerin öğrenim gördükleri anabilim dalına göre dağılımları incelendiğinde en fazla öğrenci sayısına sahip olan anabilim dalının sınıf eğitimi (\%26.4) olduğu, en az katılımın olduğu anabilim dalının ise bilgisayar ve öğretim teknolojileri (\%4.6), müzik (\%4.6) ve resim eğitimi (\%4.6) anabilim dalları olduğu görülmektedir. Öğrencilerin \%81.5'i 20-23 yaşları arasındadır. Katılımcıların \%40.5'i A1 seviyesinde, \%49.9’u A2 seviyesinde, \%9.5’i ise B1 düzeyinde İngilizce yetkinliğine sahiptir. 


\section{Veri Toplama Araçları}

Çalışma kapsamında araştırmacılar tarafından geliştirilen veri toplama aracı, iki bölümden oluşmaktadır. Birinci bölümde, öğrencilerin cinsiyet, yaş, öğrenim görülen anabilim dalı ve İngilizce seviyelerine ilişkin demografik sorular; ikinci bölümde ise ölçek maddeleri yer almaktadır.

Bu ölçeğe ilişkin madde yazım aşamasında Diller için Avrupa Ortak Öneriler Çerçevesinde (2013) yer alan ve dört beceriyi (okuma, yazma, konuşma, dinleme) kapsayan ortak öneri düzeylerine ve ögrenenlerin yeterliklerine ilişkin ifadeler temel alınmıştır. Diller için Avrupa Ortak Öneriler Çerçevesinin (2013) yabancı dil öğretimine ilişkin açıkladığı eylem odaklı yaklaşım, yabancı dil öğretiminde yeterlilik kavramını dil düzeylerine göre ayrıntılı hale getirmiştir (Fişekçioğlu, 2019). C1 ve C2 düzeyini kapsayan yeterlikler temel alınarak ve ortak öneri düzeylerine ve öğrenenlerin yeterliklerine ilişkin ifadelerden yola çıkılarak, yurt dışı dil eğitimi bağlamında öğrencilerin öz-yeterlik beklentilerine ilişkin 62 maddeden oluşan bir taslak form oluşturulmuştur. Taslak formun maddelerinin ilgili değişkeni ölçüp ölçmediği, ölçeğin sunulan seçenekleri ile maddeler arasında uyumun olup olmadığ 1 ve yanlılık taşıyıp taşımadığının değerlendirilmesi için Ölçme ve Değerlendirme alanındaki dört uzmandan; maddelerin ölçülmeye çalışıldığı yapıyı yansıtıp yansıtmadığı ve alana uygunluğu açısından değerlendirilmesi için İngiliz Dili Eğitimi alanında uzman iki kişiden görüş alınmıştır.

Uzmanlardan alınan eleştiriler doğrultusunda ölçeğin amacına uygun olmayan ve dil açısından hatalı olduğu düşünülen maddeleri üzerinde düzeltmeler yapılmıştır. Uzmanlardan gelen önerilerde, madde sayısının çok olduğu ve madde fazlalığının cevaplayıcıları yorabileceği, bu yüzden beklenenden farklı sonuçlar alınabileceği, bunun yanı sıra bazı maddelerde anlatım bozukluklarının olduğu gibi ortak görüşler alınmıştır. Taslak formun ön uygulama öncesi küçük bir grup üzerinde uygulaması yapılmıştır. Bu grupta, esas uygulamada yer alan öğrencilerle benzer özellikler gösteren ve esas uygulamada yer almayan toplam 12 öğrenci bulunmaktadır. Ön deneme uygulamasından sonra ölçek faktör yapısını belirlemek ve güvenirlik çalışmaları için deneme uygulaması düzenlenmiştir. Ölçeğin seçenekleri (0) Fikrim yok, (1) Kesinlikle Katılmıyorum, (2) Katılmıyorum, (3) Katılıyorum ve (4) Kesinlikle Katılıyorum şeklindeki 5'li Likert tipindedir.

\section{Verilerin Analizi}

Ölçeğin kapsam geçerliliği için uzman görüşüne başvurulmuştur. Kapsam geçerliliği hakkındaki kanıtlar istatistiksel olmayıp uzman kanısına dayanır (Balcı, 2006; Tavşancıl, 2002). Görüşüne başvurulan uzmanlar İngiliz Dili Eğitimi alanından iki ve Ölçme ve Değerlendirme alanından dört öğretim üyesidir. Uzmanlara gönderilen uzman değerlendirme formu ile uzmanlardan madde havuzunun değerlendirilmesi için ölçekte yer alan her bir madde ile ilgili olarak maddenin konuyu yansıtıp yansıtmadığını "uygun" "kısmen uygun" ya da "uygun değil" şeklinde değerlendirme formunda ilgili yerlere işaretlemeleri ve dil anlatım açısından hatalı buldukları maddeleri de ölçek üzerinde düzeltmeleri istenmiştir. Uzmanların ortak görüşleri değerlendirilmeye alınarak gerekli değişiklikler yapılmıştır.

Ölçeğin faktör yapısını ortaya koyabilmek amacıyla yapılan AFA ve DFA'nın ardından ölçekte yer alan maddelerin ölçtükleri özellik açısından kişileri ayırt etmede yeterli olup olmadığının belirlenmesi amacıyla madde-toplam test korelasyonları hesaplanmıştır. Madde analizleri AFA uygulanan grup üzerinden elde edilmiştir.

Ölçeğin güvenirliğini belirlemek için Cronbach $\alpha$ iç tutarlılık katsayısı hesaplanmıştır. Bu katsayı, iki çalışma grubunun birleştirilmesiyle oluşturulan tüm veri üzerinden yürütülmüş̧ür. Ayrıca bu araştırmada anlamlılık düzeyi olarak .05 kabul edilmiştir.

\section{Bulgular}

Ölçeğin faktör yapısını belirlemek amacıyla AFA uygulanmıştır. Öncelikle AFA'nın varsayımları olan örneklem büyüklüğünün yeterliliği ve çok değişkenli normallik varsayımları sınanmıştır. Örneklemin faktör analizi için yeterli büyüklükte olup olmadığını belirlemek için Kaiser-Meyer-Olkin (KMO) katsayısı, verilerin çok değişkenli normallik varsayımını sağlayıp sağlamadığını belirlemek için ise Barlett Küresellik testi incelenmiştir. Leech, Barrett ve Morgan (2005), KMO değerini 0.50-0.60 arasında ise "kötü", 0.60-0.70 arasında ise "zayıf", 0.70-0.80 arasında ise "orta", 0.800.90 arasında ise "iyi ve 0.90 üzerinde ise "mükemmel" örneklem yeterliğini gösterdiğini belirtmişlerdir. Benzer şekilde Can'a (2018) göre de 0.70 ve üzeri için "iyi”, 0.50-0.70 arasını "yeterli” ve 0.50'nin altı yetersiz ilişkiyi sağlayacak örneklem ihtiyacı anlamına gelmektedir. Büyüköztürk (2011) ise genel bir ifadeyle, KMO'nun .60'dan yüksek olmasının örneklem büyüklüğü için yeterli olduğunu dile getirmiştir. Yapılan analiz sonucunda elde edilen KMO değeri .96'dır. Bu doğrultuda elde edilen örneklem büyüklüğünün yeterli olduğu sonucuna varılabilir. Marsh, Hau, Balla ve Grayson (1998), DFA sürecinde en uygun örneklem büyüklüğünü ve faktörü açıklayan madde sayısını simülatif veri üzerinden araştırmışlardır. Onlara göre faktörü açıklayan madde sayısı 2 veya 3 olduğunda 100 kişilik bir örneklemin yeterli olmayacağ 1 , ancak en az dört açıklayan madde olduğunda 100 kişilik bir örneklemin yeterli olabileceğini belirtmişlerdir. Çalışmada faktörleri açıklayan madde sayıları sadece bir faktörde dört, diğer faktörlerde ise daha fazladır. Bu yüzden DFA için 154 kişilik çalışma grubu yeterli görülmüştür. Ardından ikinci olarak verilerin çok değişkenli normal dağılması gerektiği varsayımı Barlett testi ile test edilmiştir. Bu testin p değerinin .05'in altında olması maddeler arasındaki ilişkilerin olduğu matrisin, ilişkilerin olmadığı birim matristen farklı olduğunu gösterir (Can, 2018). 
Yapılan test sonunda verilerin çok değişkenli normal dağıldığı gözlenmiştir $(p<.01)$. Buna göre örneklem büyüklüğü yeterlidir ve veriler çok değişkenli normallik varsayımını karşılamaktadır.

Faktör analizinde faktör yapısına karar verebilmek için dik döndürme yaklaşımlarından Varimaks rotasyon yöntemi tercih edilmiştir. Değişken sayısını azaltarak en az maddeyle en fazla bilgiyi toplamak amacından dolayı bu yöntem tercih edilmiştir. Buna göre, AFA sonucunda öz değerleri 1'den büyük dört faktör elde edilmiştir. Bu dört faktörün açıkladığı varyans oranları sırasıyla, \%21.49; \%15.96; \%12.58; \%11.44'tür. Her dört faktörün birlikte açıkladıkları toplam varyans ise $\% 61.48$ 'dir. Varimaks döndürme yöntemi kullanılarak, uygulanan faktör analizi işlemi sonucunda, 46 maddeden oluşan ölçekten, ölçeğin yapısına uymayan ya da birden fazla faktöre yük veren 22 madde ölçekten çıkarılmıştır. Faktör analizinde madde atma işlemi yapılırken öncelikle ikiden fazla faktör altında yüksek yük veren ve aralarında .10'dan daha az fark (Çokluk, Şekercioğlu, \& Büyüköztürk 2010) olan maddelerden başlanmıştır. Sonrasında iki faktörde yükssek yük veren maddelerle ölçekten madde çıkarma işlemi tek tek yapılarak devam edilmiştir. Son haliyle ölçekte kalan 24 madde, öz değeri 1'in üzerinde olan dört faktörlü bir yapı oluşturmuş̧ur. Maddeler atıldıktan sonra, ölçeğe ilişkin faktör yük değerleri Tablo 2'de sunulmuş̧tur.

Tablo 2. Ölçeğe ilişkin faktör yük değerleri ve madde-toplam korelasyonları

\begin{tabular}{|c|c|c|c|c|c|c|}
\hline Madde & Madde İfadeleri & $\begin{array}{l}\text { Faktör } 1 \\
\text { (Yazma) }\end{array}$ & $\begin{array}{c}\text { Faktör } 2 \\
\text { (Dinleme) }\end{array}$ & $\begin{array}{c}\text { Faktör 3 } \\
\text { (Konuşma) }\end{array}$ & $\begin{array}{r}\text { Faktör } 4 \\
\text { (Okuma) }\end{array}$ & $\mathbf{r}$ \\
\hline 41 & $\begin{array}{l}\text { İngilizce üst seviye bir sınavın dil bilgisi bölümünden yüksek bir puan } \\
\text { alabilirim. }\end{array}$ & .791 & & & & .83 \\
\hline 40 & İngilizce metin yazarken okuyucuya uygun bir stil seçebilirim. & .765 & & & & .74 \\
\hline 36 & $\begin{array}{l}\text { İngilizce yazma becerim anadili İngilizce olan birinin yazma seviyesine } \\
\text { yükselir. }\end{array}$ & .737 & & & & .74 \\
\hline 39 & İngilizceyi dilbilgisi hatası yapmadan metinler yazabilirim. & .735 & & & & .75 \\
\hline 42 & Karmaşık yapıları kullanarak kolayca İngilizce metinler yazabilirim. & .725 & & & & .77 \\
\hline 38 & $\begin{array}{l}\text { İngilizce üst seviye bir sınavın yazma bölümünden yüksek bir puan } \\
\text { alabilirim. }\end{array}$ & .705 & & & & .77 \\
\hline 37 & Mesleğimle alakalı İngilizce uzun raporlar yazabilirim. & .702 & & & & .76 \\
\hline 43 & İngilizce metin yazarken İngilizce deyimleri kullanabilirim. & .586 & & & & .72 \\
\hline 31 & Karmaşık konularla ilgili İngilizce metinler oluşturabilirim. & .577 & & & & .69 \\
\hline 2 & İngilizce filmleri altyazısız izlediğimde zorluk çekmeden anlayabilirim. & & .710 & & & .77 \\
\hline 5 & $\begin{array}{l}\text { Değişik toplumsal durumlardaki (örn: hastanede, bankada, öğretmen ve } \\
\text { ögrrenci arasında, yakın arkadaşlar arasında vb.) farklı İngilizce } \\
\text { kullanımlarını kolayca anlayabilirim. }\end{array}$ & & .707 & & & .79 \\
\hline 4 & $\begin{array}{l}\text { Farklı aksanlarla (örn: (İngiliz, İrlanda, Kanada, Amerikan, Avustralya vs.) } \\
\text { İngilizce konuşulduğunda konuşulanı kolayca anlayabilirim. }\end{array}$ & & .697 & & & 69 \\
\hline 7 & İngilizce yapılan grup tartışmalarında konuşulanları kolayca anlayabilirim. & & .659 & & & .78 \\
\hline 1 & İngilizceye ait deyimleri duyduğumda kolaylıkla anlayabilirim. & & .647 & & & .73 \\
\hline 3 & İngilizce yapılan uzun konuşmaları kolayca anlayabilirim. & & .605 & & & .73 \\
\hline 8 & $\begin{array}{l}\text { Kendi alanım ile ilgili İngilizce akademik bir dil içeren dersleri/sunumları } \\
\text { kolayca anlayabilirim. }\end{array}$ & & .500 & & & .73 \\
\hline 21 & Düşüncelerimi İngilizce sözlü olarak kolayca ifade edebilirim. & & & .745 & & .83 \\
\hline 20 & $\begin{array}{l}\text { İngilizceyi toplumsal amaçlar (örn: ikili ilişkiler kurmak, farklı bir gruba } \\
\text { dahil olmak vb.) için etkili bir şekilde konuşabilirim. }\end{array}$ & & & .729 & & .82 \\
\hline 26 & $\begin{array}{l}\text { Farklı ortamlarda (örn: okulda, arkadaş ortamında, bankada vb.) ortama } \\
\text { uygun şekilde İngilizce konuşabilirim. }\end{array}$ & & & .612 & & .78 \\
\hline 28 & $\begin{array}{l}\text { Mesleğimle/çalışma alanımla ilgili konularda başkalarına İngilizce sözlü } \\
\text { öneriler sunabilirim. }\end{array}$ & & & .595 & & .80 \\
\hline 14 & İngilizce metinlerde geçen örtük/imalı ifadeleri kolayca anlayabilirim. & & & & .766 & .85 \\
\hline 13 & Soyut ifadeler içeren İngilizce metinleri kolayca anlayabilirim. & & & & .695 & .80 \\
\hline 16 & İngilizce yazılmış metnin yazarının tutumunu kolayca anlayabilirim. & & & & .686 & .82 \\
\hline 15 & İngilizce yazılmış haber metinlerinin detaylarını kolayca anlayabilirim. & & & & .601 & .81 \\
\hline
\end{tabular}

*.30’un altındaki faktör yük değerleri dikkate alınmamış (Kline, 2011) ve tabloda gösterilmemiş̧ir. Ayrıca maddelerin bir faktör altında yer alabilmesi için en az .40 faktör yük değeri (Pett, Lackey, \& Sullivan, 2003) esas alınmıştır.

Tablo 2 incelendiğinde, ölçeği oluşturan maddelere ilişkin faktör yüklerinin, .500 ile .791 arasında değiştiği görülmektedir. Madde geçerliğine kanıt olarak hesaplanan madde toplam test korelasyonlarının ise .69 ile .85 arasında değiştiği belirlenmiştir. Bu doğrultuda ölçekte yer alan maddelerin, faktör toplamları ile arasındaki korelasyonların yüksek olduğu söylenebilir. Maddelerin faktörlerde aldıkları yük değerlerine bakıldığında, 24 maddeden 9'unun birinci, 7'sinin ikinci, 4'ünün üçüncü ve dördüncü faktörde yer aldığı görülmektedir. Buna göre birinci faktör, katılımcıların, yabancı dilde yazma, ikinci faktör, yabancı dilde dinleme, üçüncü faktör, yabancı dilde konuşma ve son faktör ise yabancı dilde okuma konusunda ne derecede etkili olabileceğini düşündüğünü gösteren maddelerden oluşmaktadır. AFA sonucunda elde edilen dört faktörlü yapının başka bir çalışma grubu üzerinde doğrulanıp doğrulanmadığını test etmek için DFA uygulanmıştır. Model için elde edilen uyum indeksleri incelenmiştir. DFA sonucunda elde edilen dört faktörlü modele ilişkin t değerleri Şekil 1'de yer almaktadır. 

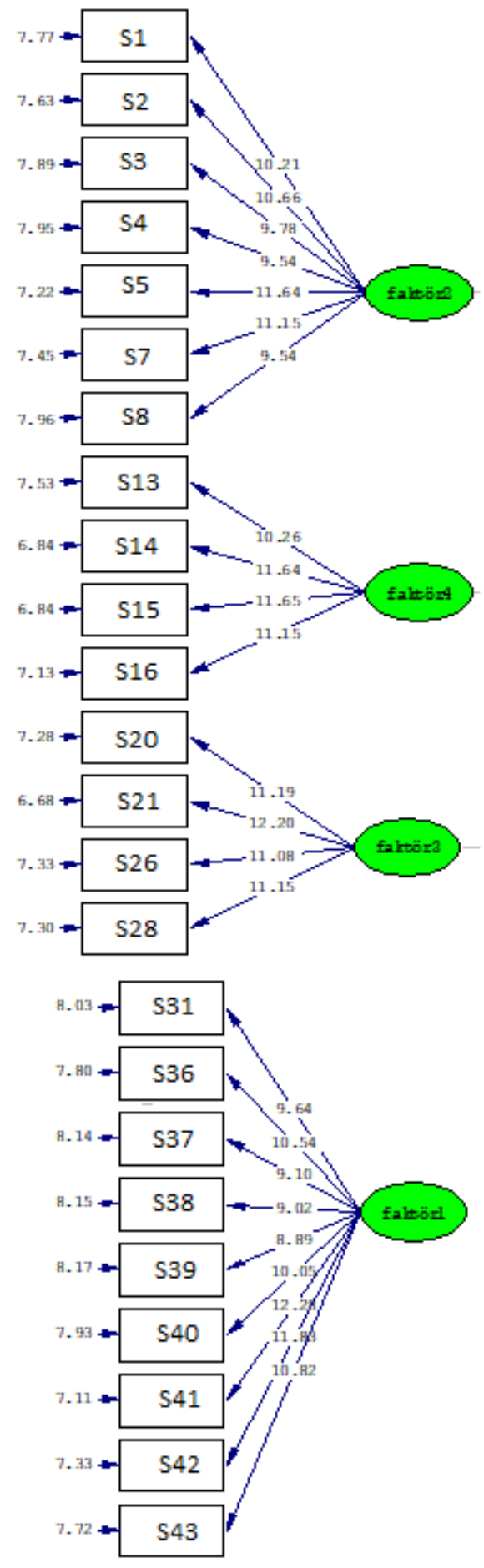

Chi-Square $=541.67, \mathrm{df}=246, \mathrm{P}$-value $=0.00000, \mathrm{RMSEA}=0.089$

* Faktör 1(yazma), faktör 2 (dinleme), faktör 3 (konuşma), faktör 4 (okuma)

Şekil 1. Doğrulayıcı faktör analizi sonuçları

Şekil 1 incelendiğinde maddelerin taşıdığı t değerleri (kırmızı ok olmadığı için) anlamlıdır. Ayrıca path diyagramı üzerinde maddelerin taşıdığı yük değerleri Ek1'de görülmektedir. Maddelerin taşıdığı yük değerleri .66 ile .83 arasında değişmektedir. Bütün maddelerin faktör yük değerlerinin .30'un üzerinde olduğu anlaşılmaktadır. Model uygunluğunun değerlendirilmesinde kullanılan, birbirinden farklı uyum iyiliği indeksleri $(\chi 2 /$ sd, RMSEA, NFI, NNFI, IFI, CFI ve RMR) ve bu indekslerin modelin kabul edilip edilmeyeceğine ilişkin sınır değerleri vardır. Uyum indekslerine ilişkin kabul edilebilir ve iyi uyum değerleri ile birlikte ölçekten elde edilen değerler Tablo 3 ’te verilmiştir. 
Tablo 3. Uyum indekslerine ilişkin iyi ve kabul edilebilir uyum ölçütleri ve ölçek değerleri

\begin{tabular}{llll}
\hline Uyum İndeksleri* & İyi Uyum & Kabul Edilebilir Uyum & Ölçek Değerleri \\
\hline $\mathrm{x}^{2} / \mathrm{sd}$ & $0 \leq \mathrm{x}^{2} / \mathrm{sd} \leq 2$ & $2 \leq \mathrm{x}^{2} / \mathrm{sd} \leq 3$ & $541.67 / 246=2.20$ \\
RMSEA & $0 \leq \mathrm{RMSEA} \leq .05$ & $.05 \leq \mathrm{RMSEA} \leq .10$ & .09 \\
$\mathrm{RMR}$ & $0 \leq \mathrm{RMR} \leq .05$ & $.05 \leq \mathrm{RMR} \leq .10$ & .08 \\
$\mathrm{NFI}$ & $.95 \leq \mathrm{NFI} \leq 1.00$ & $.90 \leq \mathrm{NFI} \leq .95$ & .93 \\
$\mathrm{NNFI}$ & $.95 \leq \mathrm{NFI} \leq 1.00$ & $.90 \leq \mathrm{NFI} \leq .95$ & .95 \\
CFI & $.95 \leq \mathrm{CFI} \leq 1.00$ & $.90 \leq \mathrm{CFI} \leq .95$ & .96 \\
$\mathrm{IFI}$ & $.95 \leq \mathrm{CFI} \leq 1.00$ & $.90 \leq \mathrm{CFI} \leq .95$ & .96 \\
\hline
\end{tabular}

*Kaynak: Schermelleh-Engel ve Moosbrugger (2003)

Tablo 3'te yer alan modelin yeterliğini ortaya koymak amaciyla incelenen uyum indekslerinden $\mathrm{X}^{2} / \mathrm{sd}(\mathrm{ki}$ kare/serbestlik derecesi), RMSEA, RMR ve NFI değerlerinin kabul edilebilir sınırlar içinde yer aldığı, NNFI, CFI ve IFI'nın iyi uyuma işaret ettiği görülmektedir. Geliştirilen ölçeğin iç tutarlılık güvenirliğine ilişkin Cronbach Alfa katsayısı, ölçeğin tümü ve alt boyutları için hesaplanmıştır. Ölçeğin tümü için hesaplanan güvenirlik değeri .94, birinci faktör için .91 , ikinci faktör için .87 , üçüncü faktör için .84 ve dördüncü faktör için ise .82 olarak bulunmuştur.

\section{Tartışma ve Öneriler}

Öğrencilerin yabancı dil öğrenme sürecine ilişkin inançlarını ve beklentilerini belirlemek, etkili öğretim stratejilerini işleme koymak ve tutarlı bir dil eğitimi sunmak açısından önemlidir (Horwitz, 1999). Yurt dışında dil eğitiminin popülerliği düşünüldüğünde, öğrencilerin bu sürece adım atmadan önce hangi inançlara ve beklentilere sahip olduklarının belirlenmesi gerekmektedir (Surtees, 2016). Yurt dışında dil eğitimi için bulunan öğrencilerin yabancı dil öğrenme inançları üzerinde gerçekleştirilen çalışmalar bulunmasına rağmen, alanyazında göz ardı edilen konulardan birisi, öğrencilerin yurt dışına çıkmadan önce sahip oldukları inançların ve beklentilerin yurt dışında bulunma tecrübelerine etkisidir (Zaykovskaya et al., 2017). Öz-yeterlik kavramı üzerine yapılan araştırmalar, öz-yeterlik inançları çok yüksek olan öğrencilerin kendine fazla güvenme ve verilen görevleri hafife alma eğiliminde olabildiklerini göstermiştir (Vancouver, Thomson, \& Williams, 2001). Bu eğilimler öğrencilerin uzun vadede düşük performans göstermelerine neden olmuştur. Her ne kadar öz-yeterlik inancının düşük olması öğrenmeyi olumsuz etkilese de, gerçeklikten uzak olan çok yüksek beklentiler de olumlu sonuçlar doğurmamaktadır. Türkiye'de yurt dışı dil eğitimi bağlamında öğrencilerin mevcut inançlan ve öz-yeterlik beklentilerini konu alan çok az çalışma olduğu ve araştırmalarda kullanılacak geçerli ve güvenilir bir ölçme aracının olmadığı görülmektedir. Dolayısıyla öğrencilerin yurt dışında dil eğitiminin sonunda ulaşabilecekleri yetkinliklere ilişkin öngördükleri öz-yeterlik inançlarını ve beklentilerini önceden tespit edecek bir veri toplama aracının geliştirilmesi önemlidir. Bu noktadan hareketle "Yurt dışı Eğitim ve İkinci Dil Öz-Yeterlik İnançları Ölçeği’" geliştirilmiştir.

Geliştirilen ölçeğin madde havuzunun oluşturulması aşamasında Ölçme ve Değerlendirme alanında ve İngiliz Dili Eğitimi alanında uzman olan kişilerin görüşlerine başvurulmuştur. Uzmanlardan gelen öneriler doğrultusunda maddelere son şekli verilmiştir. Ölçeğin faktör yapısını ortaya koyabilmek için AFA ve DFA kullanılmıştır. AFA sonucunda öz değerleri 1'den büyük 24 maddeden oluşan dört faktörlü bir yapı ortaya çıkmıştır. Bu dört faktörün toplam varyansın \%61.48'ini açıkladığı görülmüştür. Maddelerin faktör yük değerleri, .50 ile .79 arasında değişmektedir. Comrey ve Lee (1992) faktör yük değerlerinin .71 olması durumunun "mükemmel" olarak nitelendirilebileceğini belirtmektedirler. Toplamda 11 maddenin faktör yük değeri .71'in üzerinde olduğu için yük değerleri "mükemmel" olarak, yedi maddenin yük değeri .63'ün üzerinde olduğundan "çok iyi”, ayrıca geriye kalan tüm maddelerin ise faktör yük değerlerinin .50'nin üzerinde olması "iyi” şeklinde yorumlanabilir. Sonuç olarak ortak faktör yükleri kabul edilebilir değerler olan (Field, 2009) .40'ın üzerindedir. Elde edilen dört faktörlü yapının doğrulanıp doğrulanmadığını test etmek için ikinci bir çalışma grubu üzerinde DFA uygulanmıştır. Model için elde edilen uyum indekslerine $(\chi 2 / \mathrm{sd}=2.20$; RMSEA =.09; RMR=.08; NFI=.93; NNFI=.95; CFI=.96 ve IFI=.96) göre dört faktörlü yapı doğrulanmıştır. $\chi 2 / \mathrm{sd} \leq 5$ (Bollen, 1989; Sümer, 2000), RMSEA $\leq .10$ (Anderson \& Gerbing, 1984), RMR $\leq .10$ (Schermelleh-Engel \& Moosbrugger, 2003) olduğu için model iyi uyum göstermektedir.

Birinci faktör yazma, ikinci faktör dinleme, üçüncü faktör konuşma ve son faktör ise okuma olarak isimlendirilmiştir. Yazma faktöründen alınabilecek en yüksek puan 36 iken en düşük puan 0'dır. Dinleme faktöründen elde edilebilecek en yüksek puan 28 iken, bu faktörden alınabilecek en düşük puan 0'dır. Konuşma ve okuma faktörleri için alınabilecek en yüksek puan 16, en düşük puan ise 0'dır. Ölçeğin tümünden toplam puan alınabileceği gibi, dört faktörlü bir yapıya sahip olan bu ölçeğin puanlanmasında faktör temelli bir yol da izlenebilir. Ayrıca ölçekte tersine kodlama yapılacak bir madde bulunmamaktadir.

Geliştirilen bu ölçekle, yurt dışında dil kursuna gitmeyi amaçlayan öğrencilerin ileriye dönük öz-yeterlik inançlarının ve beklentilerinin öğrenciler yurt dışına gitmeden önce ölçülmesi amaçlanmaktadır. Bu sayede, özellikle Türkiye'den yurt dişına dil kursuna gitmeyi hedefleyen öğrencilerin, yurt dişına çıkmadan önce sahip oldukları inançların ve beklentilerin yurt dışında bulunma tecrübelerine etkisini inceleyen çalışmalara katkı sağlanacağ düşünülmektedir. 


\section{Kaynakça / References}

Allen, H. W., \& Dupuy, B. (2012). Study abroad, foreign language use, and the communities standard. Foreign Language Annals, 45(4), 468-493.

Amuzie, G. L., \& Winke, P. (2009). Changes in language learning beliefs as a result of study abroad. System, 37(3), $366-379$.

Anderson, J. C., \& Gerbing, D. W. (1984). The effect of sampling error on convergence, improper solutions, and goodness-of-fit indices for maximum likelihood confirmatory factor analysis. Psychometrika, 49(2), 155-173.

Badstübner, T., \& Ecke, P. (2009). Students' expectations, target language use, and perceived learning progress in a summer study abroad program in Germany. Die Unterrichtspraxis: Teaching German, 42, 41-49.

Balaman-Uçar, S. (2016). Türkiye bağlamında öz-yeterlik ve strateji kullanımı arasındaki ilişkinin araştırılması. Current Research in Education, 2(3), 186-198.

Balc1, A. (2006). Sosyal bilimlerde araştırma teknikleri. Ankara: Pegem.

Bandura, A. (1977). Social learning theory. Englewood Cliffs, NJ: Prentice Hall.

Bandura, A. (1986). Social foundations of thought and action: A social cognitive theory. Englewood Cliffs, NJ: Prentice Hall.

Bandura, A. (1994). Self-efficacy. In V. S. Ramachaudran (Ed.), Encyclopedia of human behavior (pp. 71-81). New York, NY: Academic Press.

Bandura, A. (1997). Self-efficacy: The exercise of control. New York, NY: Freeman.

Bandura, A. (1999). Social cognitive theory: An agentic perspective. Asian Journal of Social Psychology, 2(1), 21-41.

Betz, N., \& Hackett, G. (1986). Applications of self-efficacy theory to understanding career choice behavior. Journal of Social and Clinical Psychology, 4(3), 279-289.

Bonyadi, A., Nikou, F. R., \& Shahbaz, S. (2012). The relationship between EFL learners' self-efficacy beliefs and their language learning strategy use. English language teaching, 5(8), 113-121.

British Council. (2012). Student insight Turkey. Access: http://ihe.britishcouncil.org/educationintelligence/student-insight-turkey

British Council. (2013). International education perspective: Turkish students. Access: https://ei.britishcouncil.org/educationintelligence/importanceinternationaleducation-perspective-turkish-students

Busse, V. (2013). An exploration of motivation and self-beliefs of first year students of German. System, 41(2), 379-398.

Can, A. (2018). SPSS ile bilimsel araştırma sürecinde nicel veri analizi. Ankara: Pegem.

Chen, H. (2007). The relationship between EFL learners' self-efficacy beliefs and performance (Unpublished doctoral dissertation). Florida State University, USA.

Comrey, A. L., \& Lee, H. B. (1992). A first course in factor analysis. Mahwah, NJ: Lawrence Erlbaum Associates, Inc.

Cubillos, J., Chieffo L., \& Fan, C. (2008). The impact of short-term study abroad programs on L2 listening comprehension skills. Foreign Language Annals, 41, 157-185.

Cubillos, J. H., \& Ilvento, T. (2013). The impact of study abroad on students' self-efficacy perceptions. Foreign Language Annals, 45(4), 494-511.

Çokluk, Ö., Şekercioğlu, G., \& Büyüköztürk, Ş. (2010). Sosyal bilimler için çok değişkenli istatistik. SPSS ve LISREL uygulamalarl. Ankara: Pegem.

Çubukcu, F. (2008). A study on the correlation between self efficacy and foreign language learning anxiety. Journal of Theory and Practice in Education, 4(1), 148-158.

DeKeyser, R. (1990). From learning to acquisition? Monitoring in the classroom and abroad. Hispania, 73, 238-47. 
DeKeyser, R. (1991). Foreign language development during a semester abroad. In B. Freed (Ed.), Foreign language acquisition: Research and the classroom (pp. 104-119). Lexington, MA: D. C. Heath.

Dewey, D. (2004). A comparison of reading development by learners of Japanese in intensive and domestic immersion and study abroad contexts. Studies in Second Language Acquisition, 26, 303-327.

Díaz-Campos, M. (2004). Context of learning in the acquisition of Spanish second language phonology. Studies in Second Language Acquisition, 26, 249-273.

Diller İçin Avrupa Ortak Öneriler Çerçevesi Öğrenim, Öğretim ve Değerlendirme. (2013). (Çev: TELC. MEB). Erişim: https://www.telc.net/tr/sinav-katilimcilari/avrupa-ortak-oeneriler-cercevesi-aooeccefr.html

EF EPI. (2019). English Proficiency Index 2019. Access: https://bluesyemre.files.wordpress.com/2019/11/ef-english-proficiencyindex-2019.pdf

Field, A. (2009). Discovering statistics using SPSS. Thousand Oaks, CA: Sage.

Fişekçioğlu, A. (2019). Yabancı dil olarak Türkçe öğretiminde diller için Avrupa ortak öneriler çerçevesi ölçütlerine göre Türk kültürü tanımlayıcılarının oluşturulması: B1 dil düzeyi model önerisi. Motif Akademi Halkbilimi Dergisi, 12, 871 -893.

Foster, P. (2009). Lexical diversity and native-like selection: The bonus of studying abroad. In B. Richards, M. H. Daller, D. D. Malvern, P. M. Meara, J. Milton, \& J. Treffers-Daller (Eds.), Vocabulary studies in first and second language acquisition: The interface between theory and application (pp. 91-106). Basingstoke: Palgrave Macmillan.

Güvendir, E. (2017). Turkish students and their experiences during a short-term summer visit to the US. Study Abroad Research in Second Language Acquisition and International Education, 2(1), 21-52.

Hackett, G., \& Betz, N. (1981). A self-efficacy approach to the career development of women. Journal of Vocational Behavior, 18, 326-339.

Horwitz, E. K. (1999). Cultural and situational influences on foreign language learners' beliefs about language learning: A review of BALLI studies. System, 27(4), 557-576.

IALC. (2016). Study Researchel Reports. Recess: https://www.ialc.org/fileadmin/uploads/ialc/Documents/Study_Travel_Research_Reports/ialc-2016-research-trends-indemand-for-foreign-languages.pdf

ICEF Monitor. (2017). From the field: A closer look Turkish outbound market. Access: https://monitor.icef.com/2017/02/fieldcloser-look-turkish-outbound-market/

Juan-Garau, M. (2014). Oral accuracy growth after formal instruction and study abroad: Onset level, contact factors and long-term effects. In C. Pérez-Vidal (Ed.), Language acquisition in study abroad and formal instruction contexts (pp. 87-110). Amsterdam: John Benjamins.

Kaypak, E., \& Ortaçtepe, D. (2014). Language learner beliefs and study abroad: A study on English as a lingua franca (ELF). System, $42,355-367$.

Kinginger, C. (2008). Language learning in study abroad: Case studies of Americans in France. Modern Language Journal, 92(SUPPL. 1), 1-124.

Kline, P. (2014). An easy guide to factor analysis. New York, NY: Routledge.

Kroskrity, P. V. (2004). Language ideologies. In A. Duranti (Ed.), Companion to linguistic anthropology (pp. 496-517). Malden, MA: Basil Blackwell.

Landry, C. C. (2003). Self-efficacy, motivation, and outcome expectation correlates of college students' intention certainty (Unpublished doctoral thesis). Louisiana State University and Agricultural and Mechanical College, USA.

Leech, N. L., Barrett, K. C., \& Morgan, G. A. (2005). SPSS for intermediate statistics: Use and interpretation. Mahwah, NJ: Lawrence Erlbaum Associates.

Magogwe, J. M., \& Oliver, R. (2007). The relationship between language learning strategies, proficiency, age and self-efficacy beliefs: A study of language learners in Botswana. System, 35, 338-352. 
Marsh, H. W., Hau, K., Balla, J. R., \& Grayson, D. (1998). Is more ever too much? The number of indicators per factor in confirmatory factor analysis. Multivariate Behavioral Research, 33, 181-220.

Mendelson, V. G. (2004). Hindsight is 20/20, Student perceptions of language learning and the study abroad experience. Frontiers: The Interdisciplinary Journal of Study Abroad, 10, 43-63.

Milton, J., \& Meara, P. (1995). How periods abroad affect vocabulary growth in a foreign language. ITL Review of Applied Linguistics, 107/108, 17-34.

Pellegrino-Aveni, V. (1998). Student perspectives on language learning in a study abroad context. Frontiers: The Interdisciplinary Journal of Study Abroad, 4, 91-120.

Pérez-Vidal, C., \& Juan-Garau, M. (2009). The effect of study abroad on written performance. Eurosla Yearbook, 9, $269-295$.

Petersdotter L., Niehoff, E., \& Freund, P. A. (2017). International experience makes a difference: Effects of studying abroad on students' self-efficacy. Personality and Individual Differences, 10(7), 174-178.

Pett, M. A., Lackey, N. R., \& Sullivan, J. J. (2003). Making sense of factor analysis: The use of factor analysis for instrument development in health care research. Thousand Oaks, CA: Sage.

Schermelleh-Engel, K., Moosbrugger, H., \& Müller, H. (2003). Evaluating the fit of structural equation models: Tests of significance and descriptive goodness-of-fit measures. Methods of Psychological Research Online, 8(2), 23-74.

Schunk, D. H. (2003). Self-efficacy for reading and writing: Influence of modeling, goal setting and self-evaluation. Reading and Writing Quarterly, 19(2), 159-172.

Segalowitz, N., \& Freed, B. (2004). Context, contact, and cognition in oral fluency acquisition: Learning Spanish in at home and study abroad contexts. Studies in Second Language Acquisition, 26, 173-199.

Segalowitz, N., Freed, B. F., Collentine, J., Lafford, B., Lazar, N., \& Díaz-Campos, M. (2004). A comparison of Spanish second language acquisition in two different learning contexts: Study abroad and the domestic classroom. Frontiers: The Interdiscplinary Journal of Study Abroad, 10, 1-18.

Surtees, V. (2016). Beliefs about language learning in study abroad: Advocating for a language ideology approach. Frontiers: The Interdisciplinary Journal of Study Abroad, 17, 85-103.

Tanaka, K., \& Ellis, R. (2003). Study-abroad, language proficiency, and learner beliefs about language learning. JALT Journal, 25, 63-85.

Tanaka, K. (2007). Japanese students' contact with English outside the classroom during study abroad. New Zealand Studies in Applied Linguistics, 13, 36-54.

Tavşancıl, E. (2002). Tutumların ölçülmesi ve SPSS ile veri analizi. Ankara: Nobel.

T1lfarlığlu, F. T., \& Çiftçi, F. Ş. (2011). Supporting self-efficacy and learner autonomy in relation to academic success in EFL classrooms: A case study. Theory and Practice in Language Studies, 1(10), 284-294.

Torres, K. M., \& Turner, J. E. (2016). Students' foreign language anxiety and self-efficacy beliefs across different levels of university foreign language coursework. Journal of Spanish Language Teaching, 3(1), 57-73.

Vancouver, J. B., Thompson, C. M., \& Williams, A. A. (2001). The changing signs in the relationships between self-efficacy, personal goals, and performance. Journal of Applied Psychology, 86, 605-620.

Wolters, C. A., \& Rosenthal, H. (2000). The relations between students' motivational beliefs and their use of motivational strategies. International Journal of Educational Research, 33, 801-820.

Wong, M. S. L. (2005). Language learning strategies and language self-efficacy: Investigating the relationship in Malaysia. RELC Journal, 36(3), 245-269.

Yanar, B. H., \& Bümen, N. T. (2012). İngilizce ile ilgili özyeterlik ölçeğinin geliştirilmesi. Kastamonu Eğitim Dergisi. 20(1), 97110. 
Yang, N. D. (1999). The relationship between EFL learners' beliefs and learning strategy use. System, 27(4), 515-535.

Yilmaz, C. (2011). Teachers' perceptions of self-efficacy, English proficiency, and instructional strategies. Social Behavior and Personality: An International Journal, 39, 91-100.

Zaykovskaya, I., Rawal, H., \& De Costa, P. I. (2017). Learner beliefs for successful study abroad experience: A case study. System, 71, 113-121.

Zemach-Bersin, T. (2009). Selling the world. In R. Lewin (Ed.), The handbook of practice and research in study abroad (pp. 303320). New York, NY: Routledge. 
Ek-1 Maddelerin taşıdığı yük değerleri

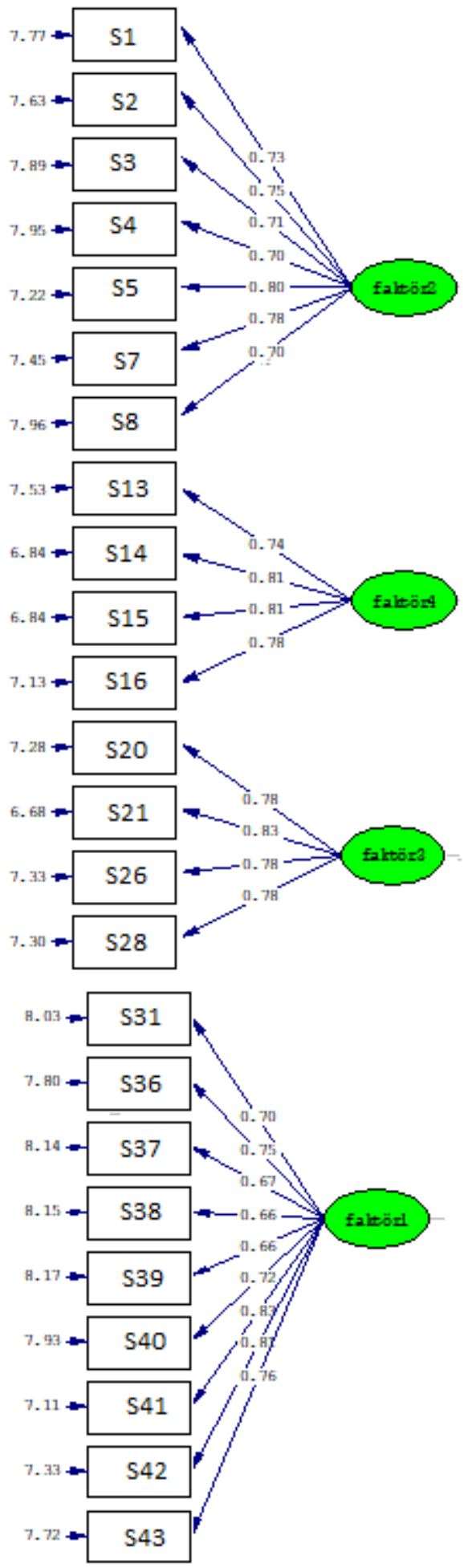


Ek-2 Yurt Dışı Eğitim ve İkinci Dil Öz-Yeterlik İnançları Ölçeği

Değerli Katılımcı,

Bu ölçeğin amacı, yurt dışında bulunan dil kurslarıyla ilgili öz-yeterlik beklentilerinizi belirlemektir.

Ölçekten elde edilecek sonuçlar bilimsel araştırma için kullanılacaktır. Katılımınız ve yardımlarınız için teşekkürler.

***Yurt dişında en fazla 6 ay sürecek bir dil kursuna gidersem, kursun bitiminde....

\begin{tabular}{|c|c|c|c|c|c|}
\hline Maddeler & $\begin{array}{l}\text { Fikrim } \\
\text { yok }\end{array}$ & $\begin{array}{l}\text { Kesinlikle } \\
\text { Katılmıyorum }\end{array}$ & Katılmıyorum & Katılıyorum & $\begin{array}{l}\text { Kesinlikle } \\
\text { Katılıyorum }\end{array}$ \\
\hline $\begin{array}{l}1 \text { (41). İngilizce üst seviye bir } \\
\text { sInavın dil bilgisi bölümünden } \\
\text { yüksek bir puan alabilirim. }\end{array}$ & $0(\quad)$ & 1() & 2() & 3() & 4() \\
\hline $\begin{array}{l}2 \text { (40). İngilizce metin yazarken } \\
\text { okuyucuya uygun bir stil } \\
\text { seçebilirim. }\end{array}$ & $0(\quad)$ & 1() & 2() & 3() & 4() \\
\hline $\begin{array}{l}3 \text { (36). İngilizce yazma becerim } \\
\text { anadili İngilizce olan birinin } \\
\text { yazma seviyesine yükselir. }\end{array}$ & $0($ ) & 1() & 2() & 3() & 4() \\
\hline $\begin{array}{l}4 \text { (39). İngilizceyi dilbilgisi hatası } \\
\text { yapmadan metinler yazabilirim. }\end{array}$ & 0() & 1() & 2() & 3() & 4() \\
\hline $\begin{array}{l}5 \text { (42). Karmaşık yapıları } \\
\text { kullanarak kolayca İngilizce } \\
\text { metinler yazabilirim. }\end{array}$ & 0() & 1() & 2() & 3() & 4() \\
\hline $\begin{array}{l}6(38) . \text { İngilizce üst seviye bir } \\
\text { sinavin yazma bölümünden } \\
\text { yüksek bir puan alabilirim. }\end{array}$ & 0() & 1() & 2() & 3() & 4() \\
\hline $\begin{array}{l}7 \text { (37). Mesleğimle alakalı İngilizce } \\
\text { uzun raporlar yazabilirim. }\end{array}$ & $0(\quad)$ & 1() & 2() & 3() & 4() \\
\hline $\begin{array}{l}8 \text { (43). İngilizce metin yazarken } \\
\text { İngilizce deyimleri kullanabilirim. }\end{array}$ & $0(\quad)$ & 1() & 2() & 3() & 4() \\
\hline $\begin{array}{l}9 \text { (31). Karmaşık konularla ilgili } \\
\text { İngilizce metinler oluşturabilirim. }\end{array}$ & $0(\quad)$ & 1() & 2() & 3() & 4() \\
\hline $\begin{array}{l}10 \text { (2). İngilizce filmleri altyazısız } \\
\text { izlediğimde zorluk çekmeden } \\
\text { anlayabilirim. }\end{array}$ & 0() & 1() & 2() & 3() & 4() \\
\hline $\begin{array}{l}11 \text { (5). Değişik toplumsal } \\
\text { durumlardaki (örn: hastanede, } \\
\text { bankada, öğretmen ve öğrenci } \\
\text { arasında, yakın arkadaşlar } \\
\text { arasında vb.) farklı İngilizce } \\
\text { kullanımları kolayca } \\
\text { anlayabilirim. }\end{array}$ & $0(\quad)$ & 1() & 2() & 3() & 4() \\
\hline $\begin{array}{l}12 \text { (4). Farklı aksanlarla (örn: } \\
\text { (İngiliz, İrlanda, Kanada, } \\
\text { Amerikan, Avustralya vs.) } \\
\text { İngilizce konuşulduğunda } \\
\text { konuşulanı kolayca anlayabilirim. }\end{array}$ & $0(\quad)$ & 1() & 2() & 3() & 4() \\
\hline $\begin{array}{l}13 \text { (7). İngilizce yapılan grup } \\
\text { tartışmalarında konuşulanları } \\
\text { kolayca anlayabilirim. }\end{array}$ & 0() & 1() & 2() & 3() & 4() \\
\hline $\begin{array}{l}14 \text { (1). İngilizceye ait deyimleri } \\
\text { duyduğumda kolaylıkla } \\
\text { anlayabilirim. }\end{array}$ & $0(\quad)$ & 1() & 2() & 3() & 4() \\
\hline
\end{tabular}




\begin{tabular}{|c|c|c|c|c|c|}
\hline $\begin{array}{l}15(3) . \text { İngilizce yapılan uzun } \\
\text { konuşmaları kolayca } \\
\text { anlayabilirim. }\end{array}$ & 0() & 1() & 2() & 3() & 4() \\
\hline $\begin{array}{l}16 \text { (8). Kendi alanım ile ilgili } \\
\text { İngilizce akademik bir dil içeren } \\
\text { dersleri/sunumları kolayca } \\
\text { anlayabilirim. }\end{array}$ & 0() & 1() & 2() & 3() & 4() \\
\hline $\begin{array}{l}17 \text { (21). Düşüncelerimi İngilizce } \\
\text { sözlü olarak kolayca ifade } \\
\text { edebilirim. }\end{array}$ & 0() & 1() & 2() & 3() & 4() \\
\hline $\begin{array}{l}18 \text { (20). İngilizceyi toplumsal } \\
\text { amaçlar (örn: ikili ilişkiler } \\
\text { kurmak, farklı bir gruba dahil } \\
\text { olmak vb.) için etkili bir şekilde } \\
\text { konuşabilirim. }\end{array}$ & 0() & 1() & 2() & 3() & 4() \\
\hline $\begin{array}{l}19 \text { (26). Farklı ortamlarda (örn: } \\
\text { okulda, arkadaş ortamında, } \\
\text { bankada vb.) ortama uygun } \\
\text { şekilde İngilizce konuşabilirim. }\end{array}$ & 0() & 1() & 2() & 3() & 4() \\
\hline $\begin{array}{l}20 \text { (28). Mesleğimle/çalışma } \\
\text { alanımla ilgili konularda } \\
\text { başkalarına İngilizce sözlü } \\
\text { öneriler sunabilirim. }\end{array}$ & 0() & 1() & 2() & 3() & 4() \\
\hline $\begin{array}{l}21(14) \text {. İngilizce metinlerde geçen } \\
\text { örtük/imalı ifadeleri kolayca } \\
\text { anlayabilirim. }\end{array}$ & 0() & 1() & 2() & 3() & 4() \\
\hline $\begin{array}{l}22(13) . \text { Soyut ifadeler içeren } \\
\text { İngilizce metinleri kolayca } \\
\text { anlayabilirim. }\end{array}$ & 0() & 1() & 2() & 3() & 4() \\
\hline $\begin{array}{l}23(16) . \text { İngilizce yazılmış metnin } \\
\text { yazarının tutumunu kolayca } \\
\text { anlayabilirim. }\end{array}$ & 0() & 1() & 2() & 3() & 4() \\
\hline $\begin{array}{l}24(15) \text {. İngilizce yazılmış haber } \\
\text { metinlerinin detaylarını kolayca } \\
\text { anlayabilirim. }\end{array}$ & 0() & 1() & 2() & 3() & 4() \\
\hline
\end{tabular}

